Review

\title{
High Content Imaging (HCI) on Miniaturized Three-Dimensional (3D) Cell Cultures
}

\section{Pranav Joshi and Moo-Yeal Lee *}

Department of Chemical \& Biomedical Engineering, Cleveland State University, 1960 East 24th Street Cleveland, Ohio, OH 44115-2214, USA; E-Mail: p.joshi18@vikes.csuohio.edu

* Author to whom correspondence should be addressed; E-Mail: m.lee68@ csuohio.edu; Tel.: +1-216-687-9399; Fax: +1-216-687-9220.

Academic Editor: Christophe A. Marquette

Received: 26 September 2015 / Accepted: 10 December 2015 / Published: 14 December 2015

\begin{abstract}
High content imaging (HCI) is a multiplexed cell staining assay developed for better understanding of complex biological functions and mechanisms of drug action, and it has become an important tool for toxicity and efficacy screening of drug candidates. Conventional HCI assays have been carried out on two-dimensional (2D) cell monolayer cultures, which in turn limit predictability of drug toxicity/efficacy in vivo; thus, there has been an urgent need to perform HCI assays on three-dimensional (3D) cell cultures. Although 3D cell cultures better mimic in vivo microenvironments of human tissues and provide an in-depth understanding of the morphological and functional features of tissues, they are also limited by having relatively low throughput and thus are not amenable to high-throughput screening (HTS). One attempt of making 3D cell culture amenable for HTS is to utilize miniaturized cell culture platforms. This review aims to highlight miniaturized 3D cell culture platforms compatible with current HCI technology.
\end{abstract}

Keywords: high content imaging; three-dimensional (3D) cell culture; miniaturized cell-based assay; predictive toxicology

\section{Introduction}

Current high-throughput screening (HTS) technology, capable of screening a large number of new compounds against an increasing number of new targets, evaluates a single endpoint involved in drug 
efficacy and toxicity. However, this approach often lacks the ability to provide highly predictive information on drug responses in vivo, which is critical to reduce the high attrition rate in downstream drug discovery pipelines. To address this issue, high content imaging (HCI) or high content screening (HCS) technology — which refers to a high-throughput, automated microscope-based assay that provides information on multiple properties or features of individual cells simultaneously with several fluorescent dyes - has been adapted to a more systematic and accurate evaluation of drug candidates [1,2]. A tremendous amount of fluorescent cell images is quantified rapidly with image analysis algorithms to provide more predictive information on toxicity and efficacy. By measuring multiple parameterswhich include target specific signals (e.g., nuclear change, organelle structure change, protein translocation, oxidative stress, apoptosis/necrosis, mitochondrial impairment, calcium homeostasis, etc.), reporter signal, morphology analysis, and phenotype profiling as readouts [1,3] — it is possible to understand the mechanisms of drug action and reduce the number of false positive and false negative results, which helps to identify efficacious lead compounds. Therefore, HCI has become an important tool in the drug discovery process in the pharmaceutical industry and has gained popularity for various cell-based research in academia.

Unfortunately, most current HCI assays employ cell monolayer cultured in 96-well plates (a.k.a., 2D cell cultures) for their convenience, low cost, and relatively high throughput. As compared to cultures mimicking tissues in vivo, these $2 \mathrm{D}$ cultured cells lose some of their phenotypic properties rapidly, and the formation of tissue-like structure is highly inhibited [4-6]. Thus, there have been enormous efforts toward developing 3D cell cultures that can maintain specific biochemical and morphological features of human cells similar to the corresponding tissues in vivo. Such platforms include human cells grown within the 3D structure of hydrogels or on 3D polymer scaffolds [7-10]. Scaffold-free systems such as the hanging droplet method has also been demonstrated as a high-throughput cell based assay platform [11]. These hanging droplet methods were shown to form tumor-like spheroids that partially mimic in vivo tumor tissue structure and have gained momentum in cancer research $[11,12]$. Although the hanging droplet plate has the potential to generate uniform 3D spheroids in droplets and promote cell-cell interactions, droplet spreading can be triggered by mechanical shock and surface fouling. This technique also lacks cell-extracellular matrix (ECM) interactions [13].

Several challenges exist in the implementation of HCI assays on a conventional 3D cell culture platform. For example, the quantitative analysis of cells present in a 3D environment in a 96-well plate is highly inconsistent and not reproducible due to the difficulty in manual handling of hydrogel and growth media [14]. Moreover, imaging and image processing poses significant challenges because cells cultured in 3D are not in a single focal plane. While such variables may not be noticeable in traditional HTS, they can become major sources of inconsistency in HCI. Furthermore, some polymer scaffolds are opaque and inadequate for imaging. When it comes to HCI, imaging technology is the key determinant of the overall success of any assay. Confocal microscopy can serve as an important tool for imaging 3D-grown cells both due to its ability to image the cells at high resolution in different optical sections and integrate the sectioned images [15]. However, slow point scanning of confocal microscopy induces low throughput of image acquisition, which can be problematic for large-scale screening and may incur some photobleaching and phototoxicity $[16,17]$. Light-sheet microscopy is an alternative, promising technology for HCI due to its ability to image biological samples in 3D for 
longer time without damaging the cell samples. However, implementing this technology in a core facility requires complete changes in experimental methods being used, and the commercial systems are still not fully accessible [18]. Moreover, an enormous amount of data generated (terabytes of data per day) further limits the implementation of this technology in standard facilities, dealing with gigabytes of data [17].

Miniaturized 3D cell culture technology, thus, can be a better choice for those who do not want to compromise throughput yet want to have better imaging features required for HCI. In contrast to conventional macroscale 3D cell culture such as in 96-well plates, miniaturized 3D cell culture allows the whole sample depth to fit within the focus depth of a normal objective due to its small dimension. Additionally, miniaturization of 3D cell culture allows for high control over microenvironmental cues, enabling more reproducible outcomes [19]. Finally, miniaturization can reduce reagent consumption, easily facilitate combinatorial approaches, and minimize the use of valuable materials, such as patient-derived cells $[13,14]$.

This article aims to summarize existing miniaturized 3D cell culture systems that have great potential in HCI applications. HCI assays and some of their major applications are described in the first section. Importance of 3D cell culture technology in HCI and the limitations of traditional 3D cell culture systems are highlighted in the second section. Finally, current miniaturized cell-based assay systems that have demonstrated HCI capabilities are discussed, along with potential challenges in implementing HCI assays on miniaturized 3D cell culture systems.

\section{High Content imaging (HCI) Assays and Their Applications}

HCI assays can probe a myriad of cellular processes at the individual cell level, including cell growth, cell viability/cytotoxicity, changes in nuclear function, apoptosis/necrosis, mitochondrial membrane potential (MMP), oxidative stress, intracellular calcium levels, and glutathione levels [20-22]. Target- and phenotype-based HCI assays are expected to provide multi-parametric information on cellular functions and processes that play pivotal roles in human toxicology. By investigating specific cellular functions at the individual cell level, one can analyze potentially heterogeneous cell populations within microenvironments of a tissue that have different properties due to oxygen/nutrient/compound diffusion limitations, or cell populations that are impacted by the micro-heterogeneous nature of ECMs. HCI assays have been implemented using various cell types such as primary cells [22], immortalized cell lines [20], and stem cells [23], for applications ranging from investigating the toxicity of nanoparticles [24] to investigating cardiotoxicity [21,25] and neurotoxicity [26,27]. HCI assays are performed using a variety of fluorescent probes, including Hoechst 33342 for nuclear morphology and cell count, calcein AM and propidium iodide (PI) for cell viability, tetramethyl rhodamine methyl ester (TMRM) for mitochondrial membrane potential (MMP), Fluo-4 AM for intracellular calcium levels, YO-PRO-1 for apoptosis, monochlorobimane (MCB) for glutathione levels, and 2',7'-dichlorodihydrofluorescein diacetate ( $\mathrm{H}_{2}$ DCFDA) for oxidative stress damage (Table 1). Additionally, a suite of HCI assays have been developed to assess mechanisms of compound toxicity and evaluate the effects on organ toxicities, such as hepatotoxicity, cardiotoxicity, and neurotoxicity (Table 2). 
Table 1. Commonly used fluorescent probes for various high content imaging (HCI) assays.

\begin{tabular}{|c|c|c|c|c|c|}
\hline $\begin{array}{l}\text { Assay/ } \\
\text { Endpoint }\end{array}$ & $\begin{array}{l}\text { Target } \\
\text { Organelle }\end{array}$ & $\begin{array}{l}\text { Fluorescent } \\
\text { Probe }\end{array}$ & Color & $\begin{array}{c}\text { Excitation/ } \\
\text { Emission (nm) }\end{array}$ & References \\
\hline \multirow{4}{*}{$\begin{array}{l}\text { Nuclear } \\
\text { morphology/ } \\
\text { Cell number }\end{array}$} & Nucleus & Hoechst 33342 & Blue & $361 / 497$ & {$[20,28-32]$} \\
\hline & Nucleus & Hoechst 33258 & Blue & $352 / 461$ & {$[23,27]$} \\
\hline & Nucleus & Draq5 & Red & $647 / 681$ & [33] \\
\hline & Nucleus & DAPI & Blue & $350 / 470$ & [34] \\
\hline \multirow{2}{*}{ Cell viability } & Cytoplasm & Propidium iodide & Red & $535 / 620$ & {$[20,29]$} \\
\hline & Cytoplasm & Calcein AM & Green & $495 / 520$ & [23] \\
\hline \multirow{2}{*}{$\begin{array}{l}\text { Cell membrane } \\
\text { permeability }\end{array}$} & Nucleus & TO-PRO-3 & Red & $642 / 661$ & {$[16,19]$} \\
\hline & Nucleus & BOBO-1 & Green & $462 / 481$ & [21] \\
\hline \multirow{3}{*}{ Apoptosis } & Nucleus & YO-PRO-1 & Green & $490 / 510$ & [35] \\
\hline & Caspase 3 & $\begin{array}{l}\text { Anti-caspase } 3 \\
\text { antibody* }\end{array}$ & $*$ & $*$ & {$[21,36]$} \\
\hline & Mitochondria & $\begin{array}{l}\text { Anti-cytochrome } \\
\text { C antibody* }\end{array}$ & $*$ & $*$ & [36] \\
\hline \multirow{2}{*}{$\begin{array}{l}\text { Mitochondrial } \\
\text { membrane } \\
\text { potential } \\
\end{array}$} & Mitochondria & TMRM & $\begin{array}{l}\text { Red- } \\
\text { Orange }\end{array}$ & $545 / 575$ & {$[20,24,29]$} \\
\hline & Mitochondria & MitoTracker & Orange & $554 / 576$ & [23] \\
\hline $\begin{array}{l}\text { Intracellular } \\
\text { calcium level }\end{array}$ & $\begin{array}{l}\text { Calcium ions in } \\
\text { cytoplasm }\end{array}$ & Fluo-4 AM & Green & $490 / 520$ & {$[20,24]$} \\
\hline $\begin{array}{l}\text { Glutathione } \\
\text { level }\end{array}$ & $\begin{array}{l}\text { Glutathione in } \\
\text { cytoplasm }\end{array}$ & $\mathrm{MCB}$ & Blue & $380 / 460$ & {$[22,28]$} \\
\hline \multirow{2}{*}{$\begin{array}{l}\text { Reactive } \\
\text { Oxygen Species } \\
\text { (ROS) } \\
\text { generation }\end{array}$} & $\begin{array}{l}\text { Oxygen radicals } \\
\text { in cytoplasm }\end{array}$ & BODIPY 665/676 & Red & $665 / 676$ & [20] \\
\hline & $\begin{array}{l}\text { Oxygen radicals } \\
\text { in cytoplasm }\end{array}$ & H2DCFDA & Green & $495 / 527$ & [29] \\
\hline $\begin{array}{l}\text { Lipid } \\
\text { accumulation }\end{array}$ & Lipids & BODIPY 493/503 & Green & $493 / 503$ & [29] \\
\hline \multirow{2}{*}{$\begin{array}{l}\text { Cell cycle } \\
\text { disruption }\end{array}$} & Nucleus & $\begin{array}{l}\text { Anti-phospho histone } \\
\text { H3 antibody* }\end{array}$ & $*$ & $*$ & {$[32,34,36]$} \\
\hline & Nucleus & EdU & Green & $495 / 519$ & {$[32,36]$} \\
\hline $\begin{array}{l}\text { Lyososomal } \\
\text { acidification }\end{array}$ & Lysosome & LysoTracker & Green & $504 / 511$ & [24] \\
\hline
\end{tabular}

Abbreviations are used as follows: 4',6-diamidino-2-phenylindole (DAPI), fluo-4 acetoxymethyl ester (fluo-4 AM), tetramethyl rhodamine methyl ester (TMRM), monochlorobimane (MCB), 2',7'-dichlorodihydrofluorescein diacetate (H2DCFDA), 5-ethynyl-2'-deoxyuridine (EdU).

* Color and excitation/emission wavelengths are changed depending on secondary antibodies conjugated with primary antibodies. 
Table 2. Multiple parameters used in HCI assays and their applications in various areas of research.

\begin{tabular}{|c|c|c|c|}
\hline Research Areas & Applications & HCI Assays & References \\
\hline \multirow{9}{*}{ Toxicology } & $\begin{array}{l}\text { Screening of compounds } \\
\text { for cytotoxicity }\end{array}$ & $\begin{array}{l}\text { Apoptosis, necrosis, and measurement of } \\
\text { cell numbers and morphological features }\end{array}$ & {$[34]$} \\
\hline & $\begin{array}{l}\text { Hepatotoxicity screening } \\
\text { with HepaRG cells }\end{array}$ & $\begin{array}{l}\text { Cell count, nuclear size, and in-cell } \\
\text { CYP3A4 expression }\end{array}$ & {$[28]$} \\
\hline & $\begin{array}{l}\text { Hepatotoxicity screening } \\
\text { with iPSC-derived } \\
\text { hepatocytes }\end{array}$ & $\begin{array}{l}\text { Cell viability, cell shape, cell area, } \\
\text { nuclear shape, mitochondria potential, } \\
\text { autophagy, and phospholipidosis }\end{array}$ & [23] \\
\hline & $\begin{array}{l}\text { Identification of drugs } \\
\text { inducing steatosis }\end{array}$ & $\begin{array}{l}\text { Lipid content, ROS generation, MMP, } \\
\text { cell viability, and cell count }\end{array}$ & [29] \\
\hline & $\begin{array}{l}\text { Hepatotoxicity screening } \\
\text { and mechanisms of drug } \\
\text { action }\end{array}$ & $\begin{array}{l}\text { Cell viability, nuclear morphology, lipid } \\
\text { peroxidation, MMP, and intracellular } \\
\text { calcium concentration }\end{array}$ & {$[20]$} \\
\hline & $\begin{array}{l}\text { Cardiotoxicity screening } \\
\text { with stem cell-derived } \\
\text { cardiomyocytes }\end{array}$ & $\begin{array}{l}\text { Nuclear morphology, MMP, apoptosis, } \\
\text { and cell membrane permeability }\end{array}$ & {$[21]$} \\
\hline & $\begin{array}{l}\text { Developmental } \\
\text { neurotoxicity with neurons }\end{array}$ & $\begin{array}{l}\text { Quantification of } \beta \text { III-tubulin (neurite } \\
\text { marker), pNF (axonal marker), and } \\
\text { MAP2 (dendrites marker) }\end{array}$ & [27] \\
\hline & $\begin{array}{l}\text { Mechanism of drug action } \\
\text { for inhibiting tumor cell } \\
\text { growth }\end{array}$ & $\begin{array}{l}\text { Apoptosis, cell cycle disruption, DNA } \\
\text { damage, and cellular morphology }\end{array}$ & [36] \\
\hline & $\begin{array}{l}\text { Developmental } \\
\text { neurotoxicity }\end{array}$ & $\begin{array}{l}\text { Metabolic activity with resazurin, } \\
\text { nuclear morphology, neurite outgrowth, } \\
\text { and cell viability }\end{array}$ & {$[26]$} \\
\hline Nanotoxicology & $\begin{array}{l}\text { Cytotoxicity of amine- } \\
\text { modified polystyrene } \\
\text { nanoparticles }\end{array}$ & $\begin{array}{l}\text { Nuclear morphology, MMP, cytosolic } \\
\text { calcium, lysosomal acidification, and } \\
\text { plasma membrane permeability }\end{array}$ & {$[24]$} \\
\hline \multirow{3}{*}{ Cancer } & $\begin{array}{l}\text { Inhibition of STAT3 } \\
\text { pathways in head and neck } \\
\text { cancer }\end{array}$ & $\begin{array}{l}\text { Nuclear morphology and pSTAT3-Y705 } \\
\text { staining }\end{array}$ & {$[30]$} \\
\hline & $\begin{array}{l}\text { Identification of phage } \\
\text { antibodies that bind to } \\
\text { tumor cells via macro } \\
\text { pinocytosis }\end{array}$ & $\begin{array}{l}\text { Detection of cell-associated IgG, } \\
\text { cell-associated phage, and nuclei }\end{array}$ & [31] \\
\hline & $\begin{array}{l}\text { Up-regulation of Pfn-1 in } \\
\text { metastatic breast cancer }\end{array}$ & $\begin{array}{l}\text { Cell migration, chromatin condensation, } \\
\text { cell density, cell size, nucleus area, actin } \\
\text { content, and actin fiber }\end{array}$ & {$[37]$} \\
\hline Infectious Disease & $\begin{array}{l}\text { Cell cycle arrest by Ebola } \\
\text { virus infection }\end{array}$ & $\begin{array}{l}\text { Quantification of cells in S-phase and } \\
\text { M-phase, nuclear size, and nuclear } \\
\text { intensity }\end{array}$ & {$[32]$} \\
\hline
\end{tabular}


Table 2. Cont.

\begin{tabular}{clll}
\hline Research Areas & Applications & HCI Assays & References \\
\hline & $\begin{array}{l}\text { Screening of protease- } \\
\text { inhibiting compounds } \\
\text { against rift valley fever } \\
\text { virus }\end{array}$ & $\begin{array}{l}\text { Detection of Gn antibody staining, } \\
\text { nuclear and cytoplasmic intensities of G } \\
\text { signal, nuclear size, and nuclear intensity }\end{array}$ & [38] \\
\cline { 2 - 5 } & $\begin{array}{l}\text { Burkholderia } \\
\text { pseudomallei (Bp)- } \\
\text { induced formation of } \\
\text { multinucleated giant cells } \\
\text { infectious Disease }\end{array}$ & $\begin{array}{l}\text { Cell number, area, number of bacterial } \\
\text { spots, and anti-Bp antibody staining }\end{array}$ & [39] \\
\cline { 2 - 5 } & $\begin{array}{l}\text { Screening of compounds } \\
\text { against Chagas disease }\end{array}$ & $\begin{array}{l}\text { Number of nuclei, amastigotes, and } \\
\text { percentage of infected cells per well }\end{array}$ & [33] \\
\cline { 2 - 5 } & $\begin{array}{l}\text { Identification of Coxiella } \\
\text { burnetii bacterial factors } \\
\text { involved in host cell } \\
\text { interaction }\end{array}$ & $\begin{array}{l}\text { Nuclei number, fragmentation, area, } \\
\text { perimeter, GFP intensity of coxiella } \\
\text { colonies }\end{array}$ & [40] \\
\hline \multirow{2}{*}{$\begin{array}{l}\text { Epigenetics } \\
\text { chentification of JMJD3 } \\
\text { the role of demethylase }\end{array}$} & $\begin{array}{l}\text { Quantification of JMJD3 expression and } \\
\text { histone H3-specific antibody staining }\end{array}$ & [41] \\
\hline $\begin{array}{l}\text { Neurodegentification of drugs for } \\
\text { Disorder }\end{array}$ & $\begin{array}{l}\text { Number of somata, area of somata, } \\
\text { neurite length, and neurite area }\end{array}$ & [42] \\
\hline
\end{tabular}

Abbreviations are used as follows: induced pluripotent stem cell (iPSC), cytochrome P450 3A4 (CYP3A4), Pan axonal neurofilament (pNF), microtubule associated protein 2 (MAP2), signal transducer and activator of transcription 3 (STAT3), profilin 1 (Pfn-1), envelope glycoprotein (Gn), immunoglobulin G (IgG).

The application of HCI assays has been widely reported in several areas of research. However, due to the limited scope of our review, we would like to discuss few major applications of HCI, including toxicology and cancer research. The application of HCI in toxicology such as the investigation of the hepatotoxic potential of drugs is reported by several groups [15,17,23,43]. For example, Tolosa et al. measured various endpoints of drug-induced hepatotoxicity in HepG2 cells including nuclear morphology, MMP, cell viability, intracellular calcium level, and oxidative stress and evaluated hepatotoxicity of seventy-eight compounds with known mechanisms of action [20]. However, metabolism-induced hepatotoxicity has not been demonstrated because of metabolically incompetent HepG2 cells used [20]. To improve the predictability of HCI assays on metabolism-mediated toxicity, hepatic cell lines were infected with recombinant adenoviruses carrying genes for cytochrome P450 (CYP450) isoforms to transiently express drug metabolizing enzymes (DMEs) [44]. Recently, Ranade et al. demonstrated a HCI assay with a DME-expressing hepatic cell line such as HepaRG cells for hepatotoxicity screening [28]. Various toxicity parameters such as glutathione level, MMP, cytoskeletal change, and cell viability have been measured along with the expression level of CYP450s in HepaRG cells to demonstrate the metabolic competency of the cell line and relevant hepatotoxicity of metabolically competent and incompetent cells [28]. Hepatocytes derived from human induced pluripotent stem cells (hiPSCs) have been used to study general cytotoxicity and mechanism-induced hepatotoxicity of compounds by characterizing cellular and nuclear morphology, lipid accumulation, and MMP [23]. 
HiPSC-derived hepatocytes expressed various hepatic biomarkers, including lipid accumulation, tight junction formation, and glycogen storage ability comparable to primary hepatocytes, indicating an increased sensitivity and specificity of the assay when using hiPSCs [23]. Similarly, cardiotoxicity has been investigated with hiPSC-derived cardiomyocytes by evaluating apoptosis, MMP, nuclear morphology, and cell membrane permeability [21]. Additionally, HCI assays have been successfully implemented for the study of neurotoxic compounds in primary neurons [27] and immortalized neuronal precursor cells [45]. Quantification of neurite outgrowth, nuclear morphology, cell viability, and other axonal and dendritic markers are evaluated to study the effect of drugs on developing and mature neurons [26,27].

In addition to toxicity assays, HCI assays have been implemented to detect pathogens inside cells and to identify drugs against those pathogens $[40,46]$. The ability to characterize cellular phenotypes in response to bacterial and viral infections make HCI assays powerful tools in infectious disease research, including Chagas disease [33], Hepatitis C [47], and Ebola [32]. For example, Alonso-Padilla et al. evaluated the effect of potential drugs on Trypanosoma cruzi parasite (Chagas disease) and the toxicity on host cells simultaneously by measuring the number of nuclei, the number of amastigotes per cell, and the percentage of infected cells per well [33]. Efficacy of drugs against other lethal viral pathogens such as Ebola [32] and Rift Valley fever virus (RVFV) [38] have also been evaluated by measuring nuclear size, nuclear intensity, cell number, and cell area.

Moreover, HCI assays have been widely used in cancer research to study the changes of morphological and functional features such as motility, growth, proliferation, and death by anticancer drugs [36,37]. For example, Towne et al. investigated the mechanisms of tumor cell death such as apoptosis, cell cycle disruption, and DNA damage by a panel of HCI assays [36]. Activation of caspase 3 and cytochrome C release for apoptosis, phospho-histone H3 and DNA synthesis for cell cycle disruption, and phospho-histone $\mathrm{H} 2 \mathrm{AX}$ for DNA damage were measured along with cell morphology and nuclear swelling [36]. Potential inhibitors of cell motility in metastatic breast cancers have been identified by measuring cell migration, cellular and nuclear morphology, and actin depolymerization [37]. Inhibitors of oncogene signaling pathways such as STAT3 involved in development and progression of head and neck squamous cell carcinomas (HNSCC) have been screened by measuring nuclear morphology and anti-pSTAT3-Y705 antibody staining [30]. Apart from identifying compounds inhibiting cancer cell motility, growth, and progression, HCI assays have been applied to investigate drug-antibody conjugates that can bind specifically to cancer cells and deliver a drug to cellular targets [31]. In addition, it has been used to screen a library of photodynamic therapy (PDT) compounds for cancer treatment [48].

\section{Macroscale Three-Dimensional (3D) Cell Cultures Applicable to HCI}

Cells cultured in conventional 2D monolayer system vary significantly from the 3D-cultured cells in terms of their properties such as morphology, physiology, protein/gene expression, and metabolism $[4,9,49,50]$. Cells grown in 2D monolayer have limited intercellular contacts and interactions because the formation of tissue-like structure is inhibited and some of their phenotypic properties are also lost $[4,5,14,51]$. The importance of $3 \mathrm{D}$ cell culture in maintaining normal cell function such as differentiation, migration, and proliferation has been highlighted in various literatures [52-55]. Moreover, 
important biological cues are provided to cells by the ECM in response to external stimuli $[49,52]$. Therefore, various 3D cell cultures have been carried out using techniques such as hydrogel matrices [40,41], 3D hanging droplets [42,43], and liquid overlay technique [55,56] among others (Figure 1 and Table 3). Due to the limited scope of our review, we focus on 3D cell culture technologies that can be applicable to HCI. For more general information on 3D cell culture technologies, readers are recommended to read other review papers written by Montanez-Sauri et al. [13], Page et al. [49], and Justice et al. [51]. Since cell behavior and characteristics are heavily influenced by growth conditions, they are more likely to mimic in vivo characteristics in a 3D model rather than in a $2 \mathrm{D}$ model.

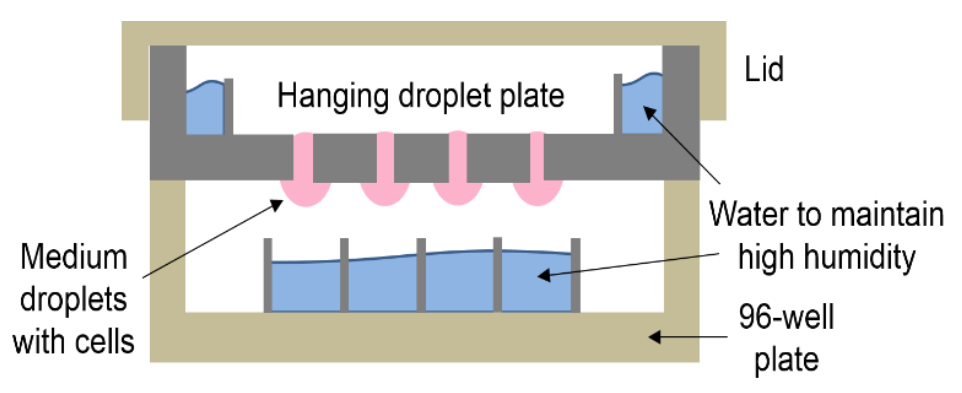

(A)

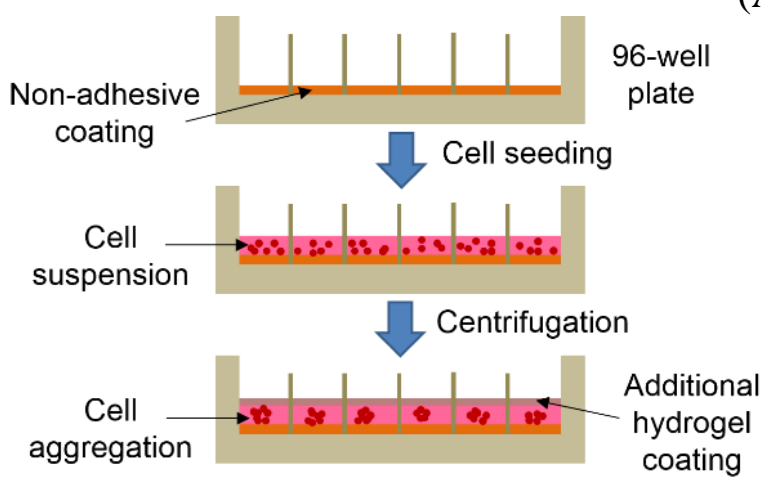

(B)

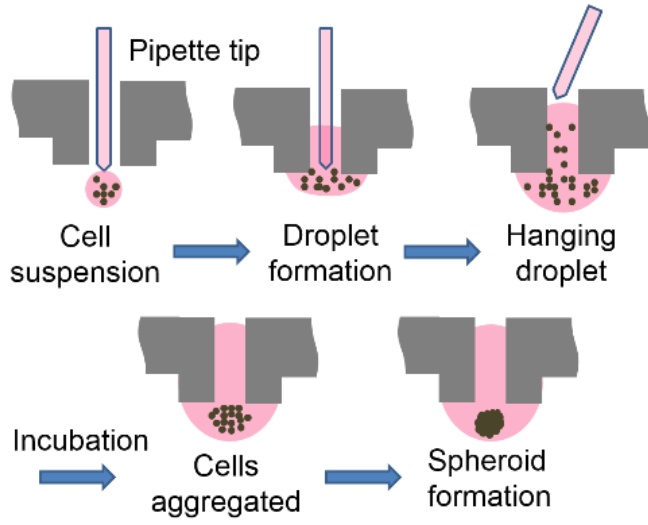

Cell growth Cells encapsulated media

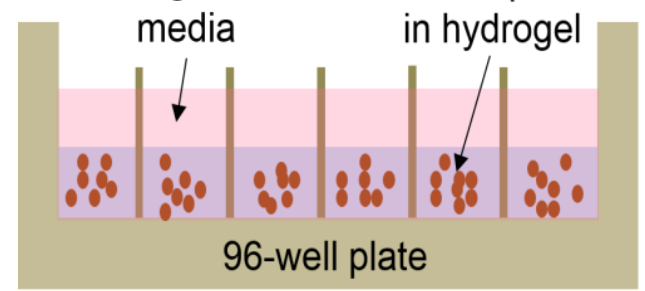

(C)

Figure 1. Commonly used 3D cell culture techniques for HCI. (A) Hanging droplet plate containing 3D spheroids. To generate 3D spheroids, cell suspension is dispensed through the access holes of the hanging droplet plate such that the droplets are attached to the hydrophilic surface. Individual cells are aggregated within hours of incubation due to gravity, forming a single spheroid. (Adapted from [57] with permission of The Royal Society of Chemistry.) (B) Liquid overlay on top of cells in a 96-well plate. The bottom of the 96-wells is coated with non-adhesive polymer in a serum-free medium, which is followed by cell seeding. The 96-well plate is centrifuged to induce cell aggregation and hydrogel in a serum-supplemented medium is overlaid on top of the aggregated cells. (C) Hydrogel matrix mixed with cells in a 96-well plate. Cell suspension is mixed with hydrogel and dispensed in the 96-well plate. Cells naturally form 3D structures within the hydrogel matrix while growing. 
Table 3. Advantages and disadvantages of commonly used 3D cell culture techniques.

\begin{tabular}{|c|c|c|c|}
\hline $\begin{array}{c}\text { Cell } \\
\text { Cultures }\end{array}$ & Advantages & Disadvantages & Applications (References) \\
\hline $\begin{array}{c}\text { Hydrogel } \\
\text { Matrix }\end{array}$ & $\begin{array}{l}\text { Cell-ECM interactions, } \\
\text { easy to incorporate } \\
\text { growth factors, in vivo- } \\
\text { like microenvironments, } \\
\text { long-term culture, } \\
\text { uniform spheroid }\end{array}$ & $\begin{array}{l}\text { Cumbersome to dispense cells in } \\
\text { hydrogels and change growth } \\
\text { media, thus low throughput, } \\
\text { difficult to retrieve cells after 3D } \\
\text { formation }\end{array}$ & $\begin{array}{l}\text { In vitro angiogenesis and drug } \\
\text { testing }[57,58] \text {; } \\
\text { Drug response study }[14,59] \text {; } \\
\text { Cancer research }[60]\end{array}$ \\
\hline $\begin{array}{c}\text { Hanging } \\
\text { Droplet }\end{array}$ & $\begin{array}{l}\text { Simple spheroid } \\
\text { formation by gravity, } \\
\text { homogenous spheroids } \\
\text { that are easily accessible }\end{array}$ & $\begin{array}{l}\text { Labor intensive and time } \\
\text { consuming, no cell-ECM } \\
\text { interaction, difficult to change } \\
\text { growth media, transferring of } \\
\text { spheroids for analysis required, } \\
\text { sensitive to mechanical shocks }\end{array}$ & $\begin{array}{l}\text { Hepatotoxicity testing with } \\
\text { HepaRG cells [61,62]; Target } \\
\text { identification and validation } \\
\text { using RNAi [63] }\end{array}$ \\
\hline $\begin{array}{l}\text { Liquid } \\
\text { Overlay }\end{array}$ & $\begin{array}{l}\text { Simple to use, } \\
\text { inexpensive, long-term } \\
\text { culture }\end{array}$ & $\begin{array}{l}\text { Labor intensive and time } \\
\text { consuming, low throughput due } \\
\text { to the centrifugation step } \\
\text { involved, heterogeneous } \\
\text { spheroids, difficult to mass } \\
\text { produce }\end{array}$ & $\begin{array}{l}\text { Evaluation of therapeutic } \\
\text { response of anticancer } \\
\text { drugs [58]; Identification of } \\
\text { anticancer drugs [55]; } \\
\text { Hepatotoxicity testing with } \\
\text { iPSC-derived hepatocytes [64] }\end{array}$ \\
\hline
\end{tabular}

3D cell culture technology has found a niche in toxicology research due to the enhanced functionality of cellular models [62]. For example, maintenance of long-term liver-specific function and high predictability towards drug-induced hepatotoxicity have been demonstrated in several studies with 3D cell models [61,62]. Gunness et al. reported the expression of liver-specific proteins including albumin, phase I DMEs (CYP2E1 and CYPA4), and efflux transporter (MRP-2) in HepaRG cells cultured in 3D by the hanging droplet technique, which resulted in high predictability of hepatotoxicity of tested drugs [61]. Similarly, Mueller et al. demonstrated the long-term liver-specific functionality of 3D-cultured HepaRG cells with significant levels of expression of CYP3A4 and MRP-2 and production of glucose and lactate [62]. More recent work on hepatotoxicity has shown 3D culture of hepatocytes differentiated from hiPSCs to be an effective platform for drug toxicity testing, with high levels of phase I and phase II DME expression along with high levels of albumin and urea secretion and expression of various drug transporters [64]. These hepatocytes differentiated from iPSCs were shown to have greater sensitivity in predicting drug-induced hepatotoxicity along with reactive metabolite-mediated toxicity of twenty-five test compounds [64].

Significant changes in cellular morphologies and responses have been observed in primary hepatocytes and human hepatoma cell lines cultured in $2 \mathrm{D}$ versus $3 \mathrm{D}$ environments. Three-dimensional cultures of primary hepatocytes and hepatoma cell lines have been shown to exhibit liver-specific functions such as secretion of urea and albumin and expression of phase I and phase II DMEs, whereas cells cultured in 2D monolayer were shown to lose their liver-specific functions [65-67]. Moreover, cells cultured in 2D and 3D exhibit differential responses towards drugs as the 3D-cultured cells showed an increased chemoresistance to anticancer drugs [68-70] attributing to its multicellular drug resistance (MDR) characteristic [71]. 
Increased physiological relevance of 3D cell culture for toxicity testing is highly evident. However, very little effort has been put towards the miniaturization of existing 3D cell culture systems that are compatible with large-scale HCI [55,56]. The establishment of more predictive 3D cell-based screens for drug efficacy and toxicity testing requires both the development of high-throughput platforms compatible with automated robotic systems that enable rapid and reproducible testing of 3D cultures, and a fundamental understanding of the mechanisms that drive the differential response of the $2 \mathrm{D}$ and $3 \mathrm{D}$ cultures to various stimuli and environmental factors. This is a challenging task that involves the decoupling of variables such as structural organization of cells, cell-cell and cell-matrix interactions, mechanical and biochemical cues, cell density, and nutrient and drug penetration. HCI assays can play a significant role in overcoming these challenges and provide highly predictive outcomes offered by 3D cell models.

Incorporating $\mathrm{HCI}$ assays in 3D cell culture (3D HCI) helps us to decipher the mechanisms of in vivo toxicity by compounds and provides better understanding of various adverse reactions by human tissues. However, very few HCI assays have been demonstrated in 3D cell models, with the majority of them being carried out in 3D spheroid models of tumor cells for identifying anticancer drugs [72,73]. For example, Krausz et al. demonstrated the feasibility of screening anticancer drugs using 3D multicellular tumor spheroids by evaluating the size of cell colony [72]. Wenzel et al. identified compounds targeting inner non-proliferative tumor cells, where spheroids were identified by nuclei staining, and cell proliferation, viability, and apoptosis induction were quantified [73]. In addition, Reid et al. developed a 3D HCI platform to identify inhibitors of cytokeratin 5 (CK5), a biomarker of breast cancer cells, by quantifying changes in the expression level of CK5 promoter-enhanced green fluorescent protein (CK5Pro-GFP) with intensity sum and area parameters [74].

$\mathrm{HCI}$ assays on macroscale 3D culture systems pose inherent challenges as acquisition of 3D-grown cell images is highly restricted by light scattering due to the thickness of cellular models and impaired diffusion of reagents across multiple layers of cells [75,76]. Optical clearing protocols are often implemented to improve the imaging capability of 3D cell structure [76-78]. However, optical clearing agents used are often cytotoxic and may incur changes in cell and tissue morphology, thereby limiting the application of optical clearing protocols [75]. Throughput is another important factor when it comes to implementing 3D HCI assays in large-scale drug efficacy and toxicity testing. Imaging macroscale 3D cell models takes a longer time due to Z-focus position issues, and 3D-cultured cell images acquired are often inconsistent even within the same 96-well. In addition, conventional 3D cell culture systems that require relatively large assay volumes are not amenable to HTS mainly due to difficulty in handling viscous solutions. Dispensing the mixture of cell suspension and viscous hydrogel and changing growth media over time without affecting the consistency and reproducibility in 96-well plates are a challenging task [14]. Moreover, the cost of reagents and compounds in conventional 3D culture systems possesses limitation in the number of assays that can be performed for HCI [13]. Given the limitations of macroscale 3D cell culture systems, very few 3D HCI assays have been implemented. To address these issues, miniaturized 3D cell culture systems with high-throughput, HCI capability have been studied. 


\section{Miniaturized 3D Cell Culture Systems and Their Application in HCI}

Conventional macroscale 3D cell culture systems are not well suited to rapidly investigate the complex in vivo-like 3D microenvironments due to aforementioned limitations in imaging and HTS capability $[19,76,79]$. On the other hand, miniaturized 3D cell models significantly reduce assay volume and reagent consumption and provide excellent control over cellular microenvironments by precisely managing cell culture conditions in a combinatorial fashion within small dimensions. Due to the reduced sample volume required, we may be able to use expensive and scarce patient-derived cells, which may lead to enhanced predictability of in vivo drug responses in individuals [19]. Miniaturization of 3D cell models can reduce the time required for image acquisition and analysis, which makes 3D cell culture system more amenable to high-throughput HCI. Image acquisition would be much simpler due to the thin depth of Z-focus position of samples, leading to significantly increased signal-to-noise ratio [80]. Current miniaturized 3D cell culture models can be broadly classified into three categories: microwell platforms, cellular microarrays, and microfluidic devices (Figure 2). The following section summarizes these miniaturized 3D cell culture platforms and highlights several HCI assays demonstrated on these platforms (Table 4).

Table 4. Advantages and disadvantages of miniaturized 3D cell-based assay systems.

\begin{tabular}{|c|c|c|c|}
\hline $\begin{array}{l}\text { Miniaturized } \\
\text { 3D Culture } \\
\text { Systems }\end{array}$ & Advantages & Disadvantages & $\begin{array}{l}\text { Applications } \\
\text { (References) }\end{array}$ \\
\hline $\begin{array}{l}\text { Microwell } \\
\text { platform }\end{array}$ & $\begin{array}{l}\text { Control over spheroid } \\
\text { size, HCI compatible }\end{array}$ & $\begin{array}{l}\text { Cumbersome to fabricate } \\
\text { microwells manually, less work } \\
\text { done with ECMs, difficult to test } \\
\text { compounds in each microwell due } \\
\text { to well-to-well cross } \\
\text { contamination, low throughput }\end{array}$ & $\begin{array}{l}\text { Study of self-renewal and } \\
\text { differentiation of stem cell [81]; } \\
\text { Study of cancer and drug } \\
\text { development [82] }\end{array}$ \\
\hline $\begin{array}{l}\text { Cellular } \\
\text { microarray }\end{array}$ & $\begin{array}{l}\text { Easy to add } \\
\text { compounds and } \\
\text { biomaterials, cell- } \\
\text { ECM interactions } \\
\text { allowable, high } \\
\text { throughput, HCI } \\
\text { compatible }\end{array}$ & $\begin{array}{l}\text { Optimization required to prevent } \\
\text { spot detachment, temperature and } \\
\text { humidity control required to } \\
\text { minimize evaporation, relatively } \\
\text { short-term culture }\end{array}$ & $\begin{array}{l}\text { Metabolism-induced toxicity } \\
\text { [83,84]; HTS of anti-cancer drug } \\
\text { efficacy [85]; Quantification of } \\
\text { protein levels [86]; Study of } \\
\text { drug toxicity screening [87]; } \\
\text { Evaluation of ajoene toxicity } \\
\text { in vitro [88] }\end{array}$ \\
\hline $\begin{array}{l}\text { Microfluidic } \\
\text { device }\end{array}$ & $\begin{array}{l}\text { Possible to test } \\
\text { chemical gradients, } \\
\text { control of fluids and } \\
\text { cell locations to } \\
\text { specific regions, HCI } \\
\text { compatible }\end{array}$ & $\begin{array}{l}\text { Cumbersome fabrication of } \\
\text { microfluidic devices required, low } \\
\text { throughput due to manual } \\
\text { intervention and bulky pumps, } \\
\text { bubble formation, channel } \\
\text { clogging by cells }\end{array}$ & $\begin{array}{l}\text { Drug-induced cardiotoxicity } \\
\text { screening [25]; Analysis of } \\
\text { ECM interaction and response to } \\
\text { external stimuli [89] }\end{array}$ \\
\hline
\end{tabular}




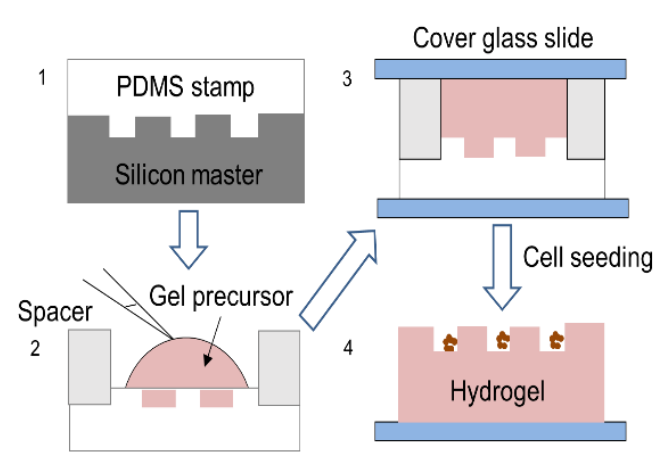

(A)

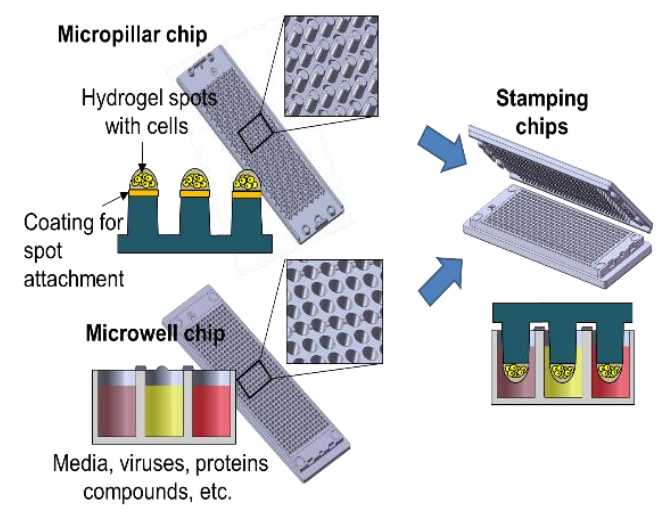

(C)

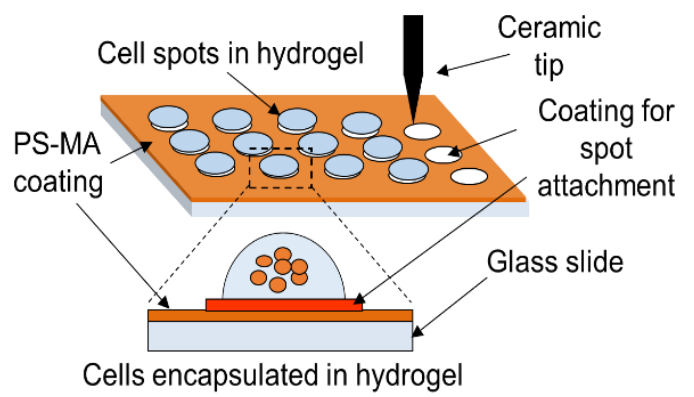

(B)

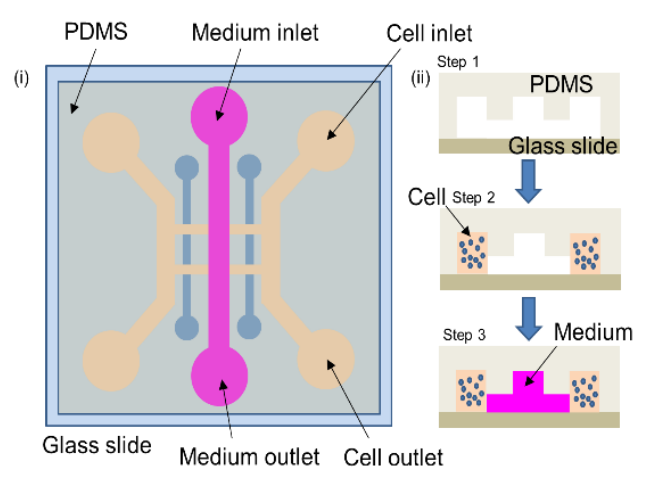

(D)

Figure 2. Miniaturized 3D cell culture systems for HCI. (A) Microwell platform (Adapted from Ref [90] with permission of The Royal Society of Chemistry). Overview of hydrogel microwell arrays fabrication process: (Step 1) A polydimethylsiloxane (PDMS) stamp containing an array of micropillars is cast on a silicon master. (Steps 2 and 3) Poly(ethylene glycol) (PEG) gel is cross-linked to contain complementary microwell array topography using the PDMS stamp as a template. (Step 4) Individual cells are trapped on the hydrogel surface after swelling and washing of the surface. (B) Cellular microarrays on a functionalized glass slide. A mixture of cells and hydrogel precursor is printed on a glass slide coated with poly(styrene-co-maleic anhydride) (PS-MA). Various polymer coating is done on top of the PS-MA coating to attach different hydrogels to the glass slide. Cells are encapsulated in a hydrogel matrix, forming 3D structures after gelation (which occurs via various mechanisms). (C) Cellular microarrays on a micropillar/microwell chip platform (Adapted by permission from Macmillan Publishers Ltd: Nature Communications, Ref [84]). Cells mixed with hydrogel are printed on top of the micropillar chip. After gelation, the micropillar chip containing cells encapsulated in hydrogel is sandwiched with a complementary microwell chip containing growth media or other reagents. (D) Microfluidic device. (i) Top view of a bilayer microfluidic chip fabricated with PDMS on top of a glass slide. Several inlet and outlet channels provide parallel access to cell suspension, growth medium and other reagents. (ii) Overview of the cell culture process in the microfluidic device: (Step 1) Bi-layer chip is fabricated with PDMS containing several channels on top of a glass slide. (Step 2) A mixture of cells and hydrogel precursor is fed from the cell inlet channel. (Step 3) A growth medium is supplied from the medium inlet channel for cell culture. 


\subsection{Microwells}

The microwell platform consists of thousands of wells with various shapes that are fabricated using photolithography techniques; this platform can be used for miniaturized 3D culture of individual or groups of cells [91]. Microwells are fabricated with non-adhesive, biocompatible materials such as polyethylene glycol (PEG), polydimethylsiloxane (PDMS), polyacrylamide, chitosan, or agarose [79,92]. Cell suspension is dispensed on the non-adhesive microwells, allowing them to settle via gravity (Figure 2A). Uniform multicellular tumor spheroid formation has been demonstrated with the ability to control the spheroid diameter in microwells for HTS of drugs [93]. Accurate control over culture conditions within microwell platforms have been explored for the study of extrinsic regulators of stem cell fate [81] and the study of drug responses in cancer cells [82]. For example, Hakanson et al. developed PEG microwells with tunable protein coating that can provide increased control over cell culture, cell-cell, and cell-matrix interactions [82]. HCI assays such as nuclei density, nuclei morphology, cell proliferation, and apoptosis were demonstrated on this platform to study drug responses against cancer cells [82]. In addition, HCI assays have been demonstrated in PDMS microwells with immune cells that were monitored in real-time to evaluate cell viability, MMP, reactive oxygen species (ROS) generation, and plasma membrane integrity for the cytotoxic effect of drugs [94]. Major limitations of the microwell systems are the potential for cross-contamination between microwells, the difficulties in dispensing multiple drugs directly into the microwells and monitoring drug responses, and the requirement of expensive and time-consuming fabrication steps.

\subsection{Cellular Microarrays}

The cellular microarray platform consists of 3D cell spots encapsulated in a hydrogel matrix on glass slides or plastic chips (Figure 2B,C). A mixture of cells and hydrogel precursor is printed onto functionalized glass slides or micropillar/microwell chips using microarray spotters, which can form gels by various methods such as temperature change, ionic cross-linking, UV irradiation and so on $[83,85]$. The cellular microarrays have been applied to various cell-based assays, including the study of cell-ECM interactions for cell-adhesion profiling [95], the testing of drug candidates and their metabolites for metabolism-induced toxicity [83,84], the quantification of protein levels in cells [86], stem cell differentiation and toxicity [96,97], and HTS of anticancer drug efficacy [85]. Recently, a micropillar chip and a complementary microwell chip have been developed for high-throughput cell-based assays such as 3D cultures of mammalian cells, enzymatic reactions, viral infection, and compound screening [84,85]. The micropillar chip, made of functional poly (styrene-co-maleic anhydride) (PS-MA), supports 3D cell cultures and comprises an array of human cells for gene expression and toxicity screening (Figure 2C).

The cellular microarray technology on the chip offers several advantages over conventional 3D cell culture approaches in cell-based assays. Specifically, it requires extremely small amounts of cells, natural and synthetic hydrogels, ECMs, growth factors, compounds, and other reagents for creating and evaluating 3D cell cultures. Cell encapsulation protocols developed are flexible and allow for culturing multiple cell types from different tissues in hydrogel layers on the chip, consequently providing more insight into potential tissue-specific toxicity of compounds [85,87]. Miniaturized 3D 
cell cultures on the chip may provide a microenvironment that simulates the in vivo ECM conditions, and therefore help to maintain the specific biochemical functions and morphological features of human tissues similar to those found in vivo. In addition, gene transduction protocols established on the chip can be applied to miniaturized 3D cell cultures to study gain- and loss-of-function genomic screening in oncology. For example, Fernandes et al. in their earlier work demonstrated the capability of HCI assays in cellular microarrays with fluorescent probes for cell viability and immunofluorescence staining and quantified the $\alpha$ subunit of hypoxia-inducible factor (HIF-1 $\alpha$ ) proteins in human pancreatic tumor cells [86]. HCI of 3D cell cultures on the chip is in early stages of research, and has yet to be fully applied towards toxicology. One of the major limitations of cellular microarrays is the spot detachment issue (i.e., the detachment of hydrogel/cell spot from the pillar chip due to poor interaction between PS-MA surface and the hydrogel used). Sophisticated surface chemistry is required to prevent the spots from getting detached from the chip surface. In addition, it is not suited for long-term cell culture due to the small dimension of cell spots.

\subsection{Microfluidic Devices}

A microfluidic device is a compact, monolithic bi-layer chip fabricated with PDMS that contains an array of microchannels and chambers for cell cultures, and inlets and outlets for providing access to desired reagents (Figure 2D) [98,99]. The advantage of microfluidic device for culturing cells under various flow conditions in a single chip has been utilized in HCI assays for toxicity tests [100]. For example, Ye et al. developed an integrated microfluidic device consisting of multiple concentration gradient generators (CGGs) and parallel cell culture chambers, and demonstrated the capability of HCI assays by screening various concentrations of anticancer drugs for induction of apoptosis in HepG2 cells [101]. Similarly, Yu et al. demonstrated the capability of parallel processing on the microfluidic device by measuring the apoptotic effect of drugs on NIH-3T3 fibroblasts, B16 melanoma, and HeLa cell lines [89]. Apart from drug toxicity screening, microfluidic devices have been utilized in various cell-signaling studies [99,102]. Cheong et al. developed an immunofluorescence assay for the quantification of individual cell signaling networks using a microfluidic device and demonstrated the HCI capability by measuring the signaling activity of kinases, nuclear factor kappa-light-chain-enhancer of activated B cells (NF-kB), and other target genes in NIH-3T3 fibroblasts in response to stimulation from cytokines and chemical inhibitors [99]. Comprehensive information on HCI assays performed in microfluidic devices can be found in the review by Cheong et al. [103]. Additionally, the production of multicellular spheroids in microfluidic devices has been recently demonstrated in areas such as anticancer therapies [104-106] and tissue engineering [107]. One of the major limitations of microfluidic devices is its relatively low throughput in terms of cell-based assays. Moreover, issues such as absorption of hydrophobic molecules, needed for frequent media change, and PDMS toxicity impose further limitations in 3D HCI [108,109].

\section{Conclusions}

High-throughput HCI on miniaturized 3D cell culture has a potential to decipher toxicodynamic and toxicokinetic traits of drugs and helps us to understand complicated toxicology pathways and related adverse responses in early stages of drug discovery. Simplifying steps for miniaturized 3D cell culture 
and integrating the cell culture platforms with automation systems for liquid handling and image acquisition/analysis are critical to implement 3D HCI. Microwell and cellular microarray platforms are more compatible with automated liquid dispensing robots such as microarray spotters than microfluidic devices, resulting in increased throughput of $\mathrm{HCI}$, whereas microfluidic devices are inherently low throughput in HCI due to the sample loading processes and large pumping units [19]. In addition, commercially available HCI-imaging systems such as Cellomics and GenePix scanners that have been developed for cells cultured on 2D surfaces may not be suited for cells cultured in 3D platforms due to Z-focus positioning and incompatibility with platform dimensions [13]. Throughput of HCI assays can be highly compromised due to time-consuming confocal imaging. In this regard, light-sheet microscopy can be a better option as it provides high-throughput 3D imaging capability without damaging cell samples. Commercial light-sheet microscopy systems are available although users may need to wait for some more time to get fully acquainted with this technology [16,18]. Needless to say, there currently is no single solution for all the imaging requirements. Various assays and applications will certainly require some level of customization by the user utilizing any imaging system. Finally, more effort will be required to generate physiologically relevant 3D cell models while maintaining the high-throughput capability of cell-based assays.

\section{Acknowledgments}

We are grateful to the funding from the National Institutes of Health (NIEHS R01ES025779) and institutional funds from the Cleveland State University (Faculty Research Development).

\section{Conflicts of Interest}

The authors declare no conflict of interest.

\section{References}

1. Zanella, F.; Lorens, J.B.; Link, W. High content screening: Seeing is believing. Trends Biotechnol. 2010, 28, 237-245, doi:10.1016/j.tibtech.2010.02.005.

2. Buchser, W.; Collins, M.; Garyantes, T.; Guha, R.; Haney, S.; Lemmon, V.; Li, Z.; Trask, O.J.J. Assay development guidelines for image-based high content screening, high content analysis and high content imaging. In Assay Guidance Manual; Eli Lilly \& Company and the National Center for Advancing Translational Sciences: Bethesda, MD, USA, 2012; pp. 1-69.

3. Van Vliet, E.; Danesian, M.; Beilmann, M.; Davies, A.; Fava, E.; Fleck, R.; Julé, Y.; Kansy, M.; Kustermann, S.; Macko, P.; et al. Current Approaches and Future Role of High Content Imaging in Safety Sciences and Drug Discovery. ALTEX 2014, 31, 479-493, doi:10.14573/altex.1405271.

4. Pampaloni, F.; Reynaud, E.G.; Stelzer, E.H.K. The third dimension bridges the gap between cell culture and live tissue. Nat. Rev. Mol. Cell Biol. 2007, 8, 839-845, doi:10.1038/nrm2236.

5. Haycock, J. 3D cell culture: A review of current approaches and techniques. In 3D Cell Culture: Methods and Protocols; Humana Press: New York, NY, USA; 2011; Volume 695, pp. 243-259.

6. Lee, J.; Cuddihy, M.J.; Kotov, N.A. Three-dimensional cell culture matrices: State of the art. Tissue Eng. Part B Rev. 2008, 14, 61-86, doi:10.1089/teb.2007.0150. 
7. Wei, J.; Han, J.; Zhao, Y.; Cui, Y.; Wang, B.; Xiao, Z.; Chen, B.; Dai, J. The importance of three-dimensional scaffold structure on stemness maintenance of mouse embryonic stem cells. Biomaterials 2014, 35, 7724-7733, doi:10.1016/j.biomaterials.2014.05.060.

8. Rimann, M.; Graf-Hausner, U. Synthetic 3D multicellular systems for drug development. Curr. Opin. Biotechnol. 2012, 23, 803-809, doi:10.1016/j.copbio.2012.01.011.

9. Breslin, S.; O’Driscoll, L. Three-dimensional cell culture: The missing link in drug discovery. Drug Discov. Today 2013, 18, 240-249, doi:10.1016/j.drudis.2012.10.003.

10. Panzavolta, S.; Torricelli, P.; Amadori, S.; Parrilli, A.; Rubini, K.; Della Bella, E.; Fini, M.; Bigi, A. 3D interconnected porous biomimetic scaffolds: In vitro cell response. J. Biomed. Mater. Res. Part A 2013, 101, 3560-3570, doi:10.1002/jbm.a.34662.

11. Hsiao, A.Y.; Tung, Y.-C.; Qu, X.; Patel, L.R.; Pienta, K.J.; Takayama, S. 384 hanging drop arrays give excellent Z-factors and allow versatile formation of co-culture spheroids. Biotechnol. Bioeng. 2012, 109, 1293-1304, doi:10.1002/bit.24399.

12. Cavnar, S.P.; Salomonsson, E.; Luker, K.E.; Luker, G.D.; Takayama, S. Transfer, Imaging, and Analysis Plate for Facile Handling of 384 Hanging Drop 3D Tissue Spheroids. J. Lab. Autom. 2014, 19, 208-214, doi:10.1177/2211068213504296.

13. Montanez-Sauri, S.I.; Beebe, D.J.; Sung, K.E. Microscale screening systems for 3D cellular microenvironments: Platforms, advances, and challenges. Cell. Mol. Life Sci. 2015, 72, 237-249, doi:10.1007/s00018-014-1738-5.

14. Lee, D.W.; Yi, S.H.; Jeong, S.H.; Ku, B.; Kim, J.; Lee, M.-Y. Plastic pillar inserts for three-dimensional (3D) cell cultures in 96-well plates. Sens. Actuators B Chem. 2013, 177, 78-85, doi:10.1016/j.snb.2012.10.129.

15. Lang, P.; Yeow, K.; Nichols, A.; Scheer, A. Cellular imaging in drug discovery. Nat. Rev. Drug Discov. 2006, 5, 343-356, doi:10.1053/j.gastro.2006.06.028.

16. Jahr, W.; Schmid, B.; Schmied, C.; Fahrbach, F.O.; Huisken, J. Hyperspectral light sheet microscopy. Nat. Commun. 2015, 6, 1-7, doi:10.1038/ncomms8990.

17. Scherf, N.; Huisken, J. The smart and gentle microscope. Nat. Biotechnol. 2015, 33, 815-818, doi:10.1038/nbt.3310.

18. Reynaud, E.G.; Peychl, J.; Huisken, J.; Tomancak, P. Guide to light-sheet microscopy for adventurous biologists. Nat. Methods 2015, 12, 30-34, doi:10.1038/nmeth.3222.

19. Håkanson, M.; Cukierman, E.; Charnley, M. Miniaturized pre-clinical cancer models as research and diagnostic tools. Adv. Drug Deliv. Rev. 2014, 69-70, 52-66, doi:10.1016/j.addr.2013.11.010.

20. Tolosa, L.; Pinto, S.; Donato, M.T.; Lahoz, A.; Castell, J.V.; O’Connor, J.E.; Gómez-Lechón, M.J.; Castell, V.; Connor, J.E.O.; Jose, M. Development of a Multiparametric Cell-based Protocol to Screen and Classify the Hepatotoxicity Potential of Drugs. Toxicol. Sci. 2012, 127, 187-198, doi:10.1093/toxsci/kfs083.

21. Mioulane, M.; Foldes, G.; Ali, N.N.; Schneider, M.D.; Harding, S.E. Development of high content imaging methods for cell death detection in human pluripotent stem cell-derived cardiomyocytes. J. Cardiovasc. Transl. Res. 2012, 5, 593-604, doi:10.1007/s12265-012-9396-1.

22. Xu, J.J.; Henstock, P.V.; Dunn, M.C.; Smith, A.R.; Chabot, J.R.; de Graaf, D. Cellular imaging predictions of clinical drug-induced liver injury. Toxicol. Sci. 2008, 105, 97-105, doi:10.1093/toxsci/kfn109. 
23. Sirenko, O.; Hesley, J.; Rusyn, I.; Cromwell, E.F. High-content assays for hepatotoxicity using induced pluripotent stem cell-derived cells. Assay Drug Dev. Technol. 2014, 12, 43-54, doi:10.1089/adt.2013.520.

24. Anguissola, S.; Garry, D.; Salvati, A.; Brien, P.J.O.; Dawson, K.A. High Content Analysis Provides Mechanistic Insights on the Pathways of Toxicity Induced by Amine-Modified Polystyrene Nanoparticles. PLoS ONE 2014, 9, doi:10.1371/journal.pone.0108025.

25. Kim, M.J.; Lee, S.C.; Pal, S.; Han, E.; Song, J.M. High-content screening of drug-induced cardiotoxicity using quantitative single cell imaging cytometry on microfluidic device. Lab Chip 2011, 11, 104-114, doi:10.1039/c0lc00110d.

26. Krug, A.K.; Balmer, N.V.; Matt, F.; Schönenberger, F.; Merhof, D.; Leist, M. Evaluation of a human neurite growth assay as specific screen for developmental neurotoxicants. Arch. Toxicol. 2013, 87, 2215-2231, doi:10.1007/s00204-013-1072-y.

27. Harrill, J.A.; Robinette, B.L.; Freudenrich, T.; Mundy, W.R. Use of high content image analyses to detect chemical-mediated effects on neurite sub-populations in primary rat cortical neurons. Neurotoxicology 2013, 34, 61-73, doi:10.1016/j.neuro.2012.10.013.

28. Ranade, A.R.; Wilson, M.S.; Mcclanahan, A.M.; Ball, A.J. High Content Imaging and Analysis Enable Quantitative in Situ Assessment of CYP3A4 Using Cryopreserved Differentiated HepaRG Cells. J. Toxicol. 2014, 2014, 1-12, doi:10.1155/2014/291054.

29. Donato, M.T.; Tolosa, L.; Jiménez, N.; Castell, J.V.; Gómez-Lechón, M.J. High-content imaging technology for the evaluation of drug-induced steatosis using a multiparametric cell-based assay. J. Biomol. Screen. 2012, 17, 394-400, doi:10.1177/1087057111427586.

30. Johnston, P.A.; Sen, M.; Hua, Y.; Camarco, D.; Shun, T.Y.; Lazo, J.S.; Grandis, J.R. High-Content pSTAT3/1 Imaging Assays to Screen for Selective Inhibitors of STAT3 Pathway Activation in Head and Neck Cancer Cell Lines. Assay Drug Dev. Technol. 2014, 12, 55-79, doi:10.1089/adt.2013.524.

31. Ha, K.D.; Bidlingmaier, S.M.; Zhang, Y.; Su, Y.; Liu, B. High-content Analysis of Antibody Phage-display Library Selection Outputs Identifies Tumor Selective Macropinocytosis-Dependent Rapidly Internalizing Antibodies. Mol. Cell. Proteom. 2014, 13, 3320-3331, doi:10.1074/ mcp.M114.039768.

32. Kota, K.P.; Benko, J.G.; Mudhasani, R.; Retterer, C.; Tran, J.P.; Bavari, S.; Panchal, R.G. High content image based analysis identifies cell cycle inhibitors as regulators of ebola virus infection. Viruses 2012, 4, 1865-1877, doi:10.3390/v4101865.

33. Alonso-Padilla, J.; Cotillo, I.; Presa, J.L.; Cantizani, J.; Pena, I.; Bardera, A.I.; Martin, J.J.; Rodriguez, A. Automated High-Content Assay for Compounds Selectively Toxic to Trypanosoma cruzi in a Myoblastic Cell Line. PLoS Negl. Trop. Dis. 2015, 9, 1-17, doi:10.1371/ journal.pntd.0003493.

34. Martin, H.L.; Adams, M.; Higgins, J.; Bond, J.; Morrison, E.E.; Bell, S.M.; Warriner, S.; Nelson, A.; Tomlinson, D.C. High-content, high-throughput screening for the identification of cytotoxic compounds based on cell morphology and cell proliferation markers. PLoS ONE 2014, 9, 1-8, doi:10.1371/journal.pone.0088338. 
35. Fujisawa, S.; Romin, Y.; Barlas, A.; Petrovic, L.M.; Turkekul, M.; Fan, N.; Xu, K.; Garcia, A.R.; Monette, S.; Klimstra, D.S.; et al. Evaluation of YO-PRO-1 as an early marker of apoptosis following radiofrequency ablation of colon cancer liver metastases. Cytotechnology 2014, 66, 259-273, doi:10.1007/s10616-013-9565-3.

36. Towne, D.L.; Nicholl, E.E.; Comess, K.M.; Galasinski, S.C.; Hajduk, P.J.; Abraham, V.C. Development of a high-content screening assay panel to accelerate mechanism of action studies for oncology research. J. Biomol. Screen. 2012, 17, 1005-1017, doi:10.1177/1087057112450050.

37. Joy, M.E.; Vollmer, L.L.; Hulkower, K.; Stern, A.M.; Peterson, C.K.; Boltz, R.C.; Roy, P.; Vogt, A. A high-content, multiplexed screen in human breast cancer cells identifies profilin-1 inducers with anti-migratory activities. PLoS ONE 2014, 9, 1-12, doi:10.1371/journal.pone.0088350.

38. Mudhasani, R.; Kota, K.P.; Retterer, C.; Tran, J.P.; Whitehouse, C.A.; Bavari, S. High Content Image-Based Screening of a Protease Inhibitor Library Reveals Compounds Broadly Active against Rift Valley Fever Virus and Other Highly Pathogenic RNA Viruses. PLoS Negl. Trop. Dis. 2014, 8, 1-16, doi:10.1371/journal.pntd.0003095.

39. Pegoraro, G.; Eaton, B.P.; Ulrich, R.L.; Lane, D.J.; Ojeda, J.F.; Bavari, S.; DeShazer, D.; Panchal, R.G. A high-content imaging assay for the quantification of the Burkholderia pseudomallei induced multinucleated giant cell (MNGC) phenotype in murine macrophages. BMC Microbiol. 2014, 14, 98, doi:10.1186/1471-2180-14-98.

40. Martinez, E.; Cantet, F.; Fava, L.; Norville, I.; Bonazzi, M. Identification of OmpA, a Coxiella burnetii Protein Involved in Host Cell Invasion, by Multi-Phenotypic High-Content Screening. PLoS Pathog. 2014, 10, doi:10.1371/journal.ppat.1004013.

41. Mulji, A.; Haslam, C.; Brown, F.; Randle, R.; Karamshi, B.; Smith, J.; Eagle, R.; Munoz-Muriedas, J.; Taylor, J.; Sheikh, A.; et al. Configuration of a High-Content Imaging Platform for Hit Identification and Pharmacological Assessment of JMJD3 Demethylase Enzyme Inhibitors. J. Biomol. Screen. 2012, 17, 108-120, doi:10.1177/1087057111418229.

42. Charoenkwan, P.; Hwang, E.; Cutler, R.W.; Lee, H.-C.; Ko, L.-W.; Huang, H.-L.; Ho, S.-Y. HCS-Neurons: Identifying phenotypic changes in multi-neuron images upon drug treatments of high-content screening. BMC Bioinform. 2013, 14, 1-15, doi:10.1186/1471-2105-14-S16-S12.

43. O’Brien, P.J.; Irwin, W.; Diaz, D.; Howard-Cofield, E.; Krejsa, C.M.; Slaughter, M.R.; Gao, B.; Kaludercic, N.; Angeline, A.; Bernardi, P.; et al. High concordance of drug-induced human hepatotoxicity with in vitro cytotoxicity measured in a novel cell-based model using high content screening. Arch. Toxicol. 2006, 80, 580-604, doi:10.1007/s00204-006-0091-3.

44. Tolosa, L.; Gómez-Lechón, M.J.; Pérez-Cataldo, G.; Castell, J.V.; Donato, M.T. HepG2 cells simultaneously expressing five P450 enzymes for the screening of hepatotoxicity: Identification of bioactivable drugs and the potential mechanism of toxicity involved. Arch. Toxicol. 2013, 87, 1115-1127, doi:10.1007/s00204-013-1012-X.

45. Schildknecht, S.; Karreman, C.; Pöltl, D.; Efrémova, L.; Kullmann, C.; Gutbier, S.; Krug, A.; Scholz, D.; Gerding, H.R.; Leist, M. Generation of genetically-modified human differentiated cells for toxicological tests and the study of neurodegenerative diseases. ALTEX 2013, 30, 427-444, doi:10.14573/altex.2013.4.427.

46. Brodin, P.; Christophe, T. High-content screening in infectious diseases. Curr. Opin. Chem. Biol. 2011, 15, 534-539, doi:10.1016/j.cbpa.2011.05.023. 
47. Berke, J.M.; Fenistein, D.; Pauwels, F.; Bobbaers, R.; Lenz, O.; Lin, T.I.; Krausz, E.; Fanning, G. Development of a high-content screening assay to identify compounds interfering with the formation of the hepatitis C virus replication complex. J. Virol. Methods 2010, 165, 268-276, doi:10.1016/j.jviromet.2010.02.007.

48. Vaz, G.M.F.; Paszko, E.; Davies, A.M.; Senge, M.O. High Content Screening as High Quality Assay for Biological Evaluation of Photosensitizers In Vitro. PLoS ONE 2013, 8, 1-17, doi:10.1371/journal.pone.0070653.

49. Page, H.; Flood, P.; Reynaud, E.G. Three-dimensional tissue cultures: Current trends and beyond. Cell Tissue Res. 2013, 352, 123-131, doi:10.1007/s00441-012-1441-5.

50. Alépée, N.; Bahinski, A.; Daneshian, M.; de Wever, B.; Fritsche, E.; Goldberg, A.; Hansmann, J.; Hartung, T.; Haycock, J.; Hogberg, H.T.; et al. State-of-the-art of 3D cultures (organs-on-a-chip) in safety testing and pathophysiology. ALTEX 2014, 31, 441-477, doi:10.14573/altex1406111.

51. Justice, B.A.; Badr, N.A.; Felder, R.A. 3D cell culture opens new dimensions in cell-based assays. Drug Discov. Today 2009, 14, 102-107, doi:10.1016/j.drudis.2008.11.006.

52. Astashkina, A.; Grainger, D.W. Critical analysis of 3-D organoid in vitro cell culture models for high-throughput drug candidate toxicity assessments. Adv. Drug Deliv. Rev. 2014, 69-70, 1-18, doi:10.1016/j.addr.2014.02.008.

53. Meng, X.; Leslie, P.; Zhang, Y.; Dong, J. Stem cells in a three-dimensional scaffold environment. Springerplus 2014, 3, 80, doi:10.1186/2193-1801-3-80.

54. Echeverria, V.; Meyvantsson, I.; Skoien, A.; Worzella, T.; Lamers, C.; Hayes, S. An automated high-content assay for tumor cell migration through 3-dimensional matrices. J. Biomol. Screen. 2010, 15, 1144-1151, doi:10.1177/1087057110378890.

55. Li, Q.; Chen, C.; Kapadia, A.; Zhou, Q.; Harper, M.K.; Schaack, J.; LaBarbera, D.V. 3D models of epithelial-mesenchymal transition in breast cancer metastasis: High-throughput screening assay development, validation, and pilot screen. J. Biomol. Screen. 2011, 16, 141-154, doi:10.1177/1087057110392995.

56. Celli, J.P.; Rizvi, I.; Blanden, A.R.; Massodi, I.; Glidden, M.D.; Pogue, B.W.; Hasan, T. An imaging-based platform for high-content, quantitative evaluation of therapeutic response in 3D tumour models. Sci. Rep. 2014, 4, 3751, doi:10.1038/srep03751.

57. Zeitlin, B.D.; Dong, Z.; Nör, J.E. RAIN-Droplet: A novel 3D in vitro angiogenesis model. Lab. Investig. 2012, 92, 988-998, doi:10.1038/labinvest.2012.77.

58. Chwalek, K.; Tsurkan, M.V.; Freudenberg, U.; Werner, C. Glycosaminoglycan-based hydrogels to modulate heterocellular communication in in vitro angiogenesis models. Sci. Rep. 2014, 4, 1-8, doi:10.1038/srep04414.

59. Di, Z.; Klop, M.J.D.; Rogkoti, V.; le Devedec, S.E.; van de Water, B.; Verbeek, F.J.; Price, L.S.; Meerman, J.H.N. Ultra High Content Image Analysis and Phenotype Profiling of 3D Cultured Micro-Tissues. PLoS ONE 2014, 9, 1-10, doi:10.1371/journal.pone.0109688.

60. Poincloux, R.; Collin, O.; Lizárraga, F.; Romao, M.; Debray, M.; Piel, M.; Chavrier, P. Contractility of the cell rear drives invasion of breast tumor cells in 3D Matrigel. Proc. Natl. Acad. Sci. USA 2011, 108, 1943-1948, doi:10.1073/pnas.1010396108. 
61. Gunness, P.; Mueller, D.; Shevchenko, V.; Heinzle, E.; Ingelman-Sundberg, M.; Noor, F. 3D organotypic cultures of human heparg cells: A tool for in vitro toxicity studies. Toxicol. Sci. 2013, 133, 67-78, doi:10.1093/toxsci/kft021.

62. Mueller, D.; Krämer, L.; Hoffmann, E.; Klein, S.; Noor, F. 3D organotypic HepaRG cultures as in vitro model for acute and repeated dose toxicity studies. Toxicol. Vitro 2014, 28, 104-112, doi:10.1016/j.tiv.2013.06.024.

63. Thoma, C.R.; Stroebel, S.; Rösch, N.; Calpe, B.; Krek, W.; Kelm, J.M. A high-throughput-compatible 3D microtissue co-culture system for phenotypic RNAi screening applications. J. Biomol. Screen. 2013, 18, 1330-1337, doi:10.1177/1087057113499071.

64. Takayama, K.; Kawabata, K.; Nagamoto, Y.; Kishimoto, K.; Tashiro, K.; Sakurai, F.; Tachibana, M.; Kanda, K.; Hayakawa, T.; Furue, M.K.; et al. 3D spheroid culture of hESC/hiPSC-derived hepatocyte-like cells for drug toxicity testing. Biomaterials 2013, 34, 1781-1789, doi:10.1016/ j.biomaterials.2012.11.029.

65. Hoffmann, S.A.; Müller-Vieira, U.; Biemel, K.; Knobeloch, D.; Heydel, S.; Lübberstedt, M.; Nüssler, A.K.; Andersson, T.B.; Gerlach, J.C.; Zeilinger, K. Analysis of drug metabolism activities in a miniaturized liver cell bioreactor for use in pharmacological studies. Biotechnol. Bioeng. 2012, 109, 3172-3181, doi:10.1002/bit.24573.

66. Altmann, B.; Giselbrecht, S.; Weibezahn, K.-F.; Welle, A.; Gottwald, E. The three-dimensional cultivation of the carcinoma cell line HepG2 in a perfused chip system leads to a more differentiated phenotype of the cells compared to monolayer culture. Biomed. Mater. 2008, 3, 1-10, doi:10.1088/1748-6041/3/3/034120.

67. Bokhari, M.; Carnachan, R.J.; Cameron, N.R.; Przyborski, S.A. Culture of HepG2 liver cells on three dimensional polystyrene scaffolds enhances cell structure and function during toxicological challenge. J. Anat. 2007, 211, 567-576, doi:10.1111/j.1469-7580.2007.00778.x.

68. Tung, Y.-C.; Hsiao, A.Y.; Allen, S.G.; Torisawa, Y.; Ho, M.; Takayama, S. High-throughput 3D spheroid culture and drug testing using a 384 hanging drop array. Analyst 2011, 136, 473-478, doi:10.1039/c0an00609b.

69. Li, C.-L.; Tian, T.; Nan, K.-J.; Zhao, N.; Guo, Y.-H.; Cui, J.; Wang, J.; Zhang, W.-G. Survival advantages of multicellular spheroids vs. monolayers of HepG2 cells in vitro. Oncol. Rep. 2008, 20, 1465-1471.

70. Loessner, D.; Stok, K.S.; Lutolf, M.P.; Hutmacher, D.W.; Clements, J.A.; Rizzi, S.C. Bioengineered 3D platform to explore cell-ECM interactions and drug resistance of epithelial ovarian cancer cells. Biomaterials 2010, 31, 8494-8506, doi:10.1016/j.biomaterials.2010.07.064.

71. Drewitz, M.; Helbling, M.; Fried, N.; Bieri, M.; Moritz, W.; Lichtenberg, J.; Kelm, J.M. Towards automated production and drug sensitivity testing using scaffold-free spherical tumor microtissues. Biotechnol. J. 2011, 6, 1488-1496, doi:10.1002/biot.201100290.

72. Krausz, E.; de Hoogt, R.; Gustin, E.; Cornelissen, F.; Grand-Perret, T.; Janssen, L.; Vloemans, N.; Wuyts, D.; Frans, S.; Axel, A.; et al. Translation of a Tumor Microenvironment Mimicking 3D Tumor Growth Co-culture Assay Platform to High-Content Screening. J. Biomol. Screen. 2012, 18, 54-66, doi:10.1177/1087057112456874. 
73. Wenzel, C.; Riefke, B.; Gründemann, S.; Krebs, A.; Christian, S.; Prinz, F.; Osterland, M.; Golfier, S.; Räse, S.; Ansari, N.; et al. 3D high-content screening for the identification of compounds that target cells in dormant tumor spheroid regions. Exp. Cell Res. 2014, 323, 131-143, doi:10.1016/j.yexcr.2014.01.017.

74. Reid, B.G.; Jerjian, T.; Patel, P.; Zhou, Q.; Yoo, B.H.; Kabos, P.; Sartorius, C.A.; Labarbera, D.V. Live multicellular tumor spheroid models for high-content imaging and screening in cancer drug discovery. Curr. Chem. Genom. Transl. Med. 2014, 8, 27-35, doi:10.2174/2213988501408010027.

75. Ertürk, A.; Bradke, F. High-resolution imaging of entire organs by 3-dimensional imaging of solvent cleared organs (3DISCO). Exp. Neurol. 2013, 242, 57-64, doi:10.1016/j.expneurol. 2012.10.018.

76. Kabadi, P.K.; Vantangoli, M.M.; Rodd, A.L.; Leary, E.; Madnick, S.J.; Morgan, J.R.; Kane, A.; Boekelheide, K. Into the depths: Techniques for in vitro three-dimensional microtissue visualization. Biotechniques 2015, 59, 279-286, doi:10.2144/0000113889.

77. Neu, C.P.; Novak, T.; Gilliland, K.F.; Marshall, P.; Calve, S. Optical clearing in collagen- and proteoglycan-rich osteochondral tissues. Osteoarthr. Cartil. 2014, 23, 405-413, doi:10.1016/ j.joca.2014.11.021.

78. Decroix, L.; van Muylder, V.; Desender, L.; Sampaolesi, M.; Thorrez, L. Tissue clearing for confocal imaging of native and bio-artificial skeletal muscle. Biotech. Histochem. 2015, 90, 424-431, doi:10.3109/10520295.2015.1019564.

79. Khademhosseini, A.; Langer, R.; Borenstein, J.; Vacanti, J.P. Microscale technologies for tissue engineering and biology. Proc. Natl. Acad. Sci. USA 2006, 103, 2480-2487, doi:10.1109/ LISSA.2009.4906708.

80. Lindström, S.; Andersson-Svahn, H. Overview of single-cell analyses: Microdevices and applications. Lab Chip 2010, 10, 3363-3372, doi:10.1039/c0lc00150c.

81. Lutolf, M.P.; Doyonnas, R.; Havenstrite, K.; Koleckar, K.; Blau, H.M. Perturbation of single hematopoietic stem cell fates in artificial niches. Integr. Biol. Camb. 2009, 1, 59-69, doi:10.1039/b815718a.

82. Håkanson, M.; Kobel, S.; Lutolf, M.P.; Textor, M.; Cukierman, E.; Charnley, M. Controlled breast cancer microarrays for the deconvolution of cellular multilayering and density effects upon drug responses. PLoS ONE 2012, 7, doi:10.1371/journal.pone.0040141.

83. Lee, M.-Y.; Kumar, R.A.; Sukumaran, S.M.; Hogg, M.G.; Clark, D.S.; Dordick, J.S. Three-dimensional cellular microarray for high-throughput toxicology assays. Proc. Natl. Acad. Sci. USA 2008, 105, 59-63, doi:10.1073/pnas.0708756105.

84. Kwon, S.J.; Lee, D.W.; Shah, D.A.; Ku, B.; Jeon, S.Y.; Solanki, K.; Ryan, J.D.; Clark, D.S.; Dordick, J.S.; Lee, M.-Y. High-Throughput and Combinatorial Gene Expression on a Chip for Metabolism-Induced Toxicology Screening. Nat. Commun. 2014, 5, 1-16, doi:10.1037/ a0013262.Open.

85. Lee, D.W.; Choi, Y.S.; Seo, Y.J.; Lee, M.Y.; Jeon, S.Y.; Ku, B.; Kim, S.; Yi, S.H.; Nam, D.H. High-throughput screening (HTS) of anticancer drug efficacy on a micropillar/microwell chip platform. Anal. Chem. 2014, 86, doi:10.1021/ac402546b. 
86. Fernandes, T.G.; Kwon, S.-J.; Lee, M.-Y.; Clark, D.S.; Cabral, J.M.S.; Dordick, J.S. On-Chip, Cell-Based Microarray Immunofluorescence Assay for High-Throughput Analysis of Target Proteins. Anal. Chem. 2008, 80, 6633-6639.

87. Meli, L.; Jordan, E.T.; Clark, D.S.; Linhardt, R.J.; Dordick, J.S. Influence of a three-dimensional, microarray environment on human Cell culture in drug screening systems. Biomaterials 2012, 33, 9087-9096, doi:10.1016/j.biomaterials.2012.08.065.

88. Lee, D.W.; Lee, M.-Y.; Ku, B.; Yi, S.H.; Ryu, J.-H.; Jeon, R.; Yang, M. Application of the DataChip/MetaChip technology for the evaluation of ajoene toxicity in vitro. Arch. Toxicol. 2014, 88, 283-290, doi:10.1007/s00204-013-1102-9.

89. Yu, Z.T.F.; Kamei, K.; Takahashi, H.; Shu, C.J.; Wang, X.; He, G.W.; Silverman, R.; Radu, C.G.; Witte, O.N.; Lee, K.-B.; et al. Integrated microfluidic devices for combinatorial cell-based assays. Biomed. Microdev. 2009, 11, 547-555, doi:10.1007/s10544-008-9260-х.

90. Charnley, M.; Textor, M.; Khademhosseini, A.; Lutolf, M.P. Integration column: Microwell arrays for mammalian cell culture. Integr. Biol. (Camb.) 2009, 1, 625-634, doi:10.1039/b918172p.

91. Dusseiller, M.R.; Schlaepfer, D.; Koch, M.; Kroschewski, R.; Textor, M. An inverted microcontact printing method on topographically structured polystyrene chips for arrayed micro-3-D culturing of single cells. Biomaterials 2005, 26, 5917-5925, doi:10.1016/j.biomaterials.2005.02.032.

92. Lin, R.Z.; Chang, H.Y. Recent advances in three-dimensional multicellular spheroid culture for biomedical research. Biotechnol. J. 2008, 3, 1172-1184, doi:10.1002/biot.200700228.

93. Liu, T.; Winter, M.; Thierry, B. Quasi-spherical microwells on superhydrophobic substrates for long term culture of multicellular spheroids and high throughput assays. Biomaterials 2014, 35, 6060-6068, doi:10.1016/j.biomaterials.2014.04.047.

94. Zurgil, N.; Afrimzon, E.; Deutsch, A.; Namer, Y.; Shafran, Y.; Sobolev, M.; Tauber, Y.; Ravid-Hermesh, O.; Deutsch, M. Polymer live-cell array for real-time kinetic imaging of immune cells. Biomaterials 2010, 31, 5022-5029, doi:10.1016/j.biomaterials.2010.02.035.

95. Kuschel, C.; Steuer, H.; Maurer, A.N.; Kanzok, B.; Stoop, R.; Angres, B. Cell adhesion profiling using extracellular matrix protein microarrays. Biotechniques 2006, 40, 523-531, doi:10.2144/000112134.

96. Fernandes, T.G.; Kwon, S.-J.; Bale, S.S.; Lee, M.-Y.; Diogo, M.M.; Clark, D.S.; Cabral, J.M.S.; Dordick, J.S. Three-dimensional cell culture microarray for high-throughput studies of stem cell fate. Biotechnol. Bioeng. 2010, 106, 106-118, doi:10.1002/bit.22661.

97. Fernandes, T.G.; Diogo, M.M.; Clark, D.S.; Dordick, J.S.; Cabral, J.M.S. High-throughput cellular microarray platforms: Applications in drug discovery, toxicology and stem cell research. Trends Biotechnol. 2009, 27, 342-349, doi:10.1016/j.tibtech.2009.02.009.

98. Rhee, S.W.; Taylor, A.M.; Tu, C.H.; Cribbs, D.H.; Cotman, C.W.; Jeon, N.L. Patterned cell culture inside microfluidic devices. Lab Chip 2005, 5, 102-107, doi:10.1039/b403091e.

99. Cheong, R.; Wang, C.J.; Levchenko, A. High content cell screening in a microfluidic device. Mol. Cell. Proteom. 2009, 8, 433-442, doi:10.1074/mcp.M800291-MCP200.

100. Toh, Y.-C.; Lim, T.C.; Tai, D.; Xiao, G.; van Noort, D.; Yu, H. A microfluidic 3D hepatocyte chip for drug toxicity testing. Lab Chip 2009, 9, 2026-2035, doi:10.1039/b900912d.

101. Ye, N.; Qin, J.; Shi, W.; Liu, X.; Lin, B. Cell-based high content screening using an integrated microfluidic device. Lab Chip 2007, 7, 1696-1704, doi:10.1039/b711513j. 
102. Su, G.; Sung, K.E.; Beebe, D.J.; Friedl, A. Functional Screen of Paracrine Signals in Breast Carcinoma Fibroblasts. PLoS ONE 2012, 7, 1-12, doi:10.1371/journal.pone.0046685.

103. Cheong, R.; Paliwal, S.; Levchenko, A. High-content screening in microfluidic devices. Expert Opin. Drug Discov. 2010, 5, 715-720, doi:10.1517/17460441.2010.495116.

104. Alessandri, K.; Sarangi, B.R.; Gurchenkov, V.V.; Sinha, B.; Kießling, T.R.; Fetler, L.; Rico, F.; Scheuring, S.; Lamaze, C.; Simon, A.; et al. Cellular capsules as a tool for multicellular spheroid production and for investigating the mechanics of tumor progression in vitro. Proc. Natl. Acad. Sci. USA 2013, 110, 14843-14848, doi:10.1073/pnas.1309482110.

105. Ruppen, J.; Cortes-Dericks, L.; Marconi, E.; Karoubi, G.; Schmid, R.A.; Peng, R.; Marti, T.M.; Guenat, O.T. A microfluidic platform for chemoresistive testing of multicellular pleural cancer spheroids. Lab Chip 2014, 14, 1198-1205, doi:10.1039/C3LC51093J.

106. Ziółkowska, K.; Kwapiszewski, R.; Stelmachowska, A.; Chudy, M.; Dybko, A.; Brzózka, Z. Development of a three-dimensional microfluidic system for long-term tumor spheroid culture. Sens. Actuators B Chem. 2012, 173, 908-913, doi:10.1016/j.snb.2012.07.045.

107. Chan, H.F.; Zhang, Y.; Ho, Y.-P.; Chiu, Y.-L.; Jung, Y.; Leong, K.W. Rapid formation of multicellular spheroids in double-emulsion droplets with controllable microenvironment. Sci. Rep. 2013, 3, 1-8, doi:10.1038/srep03462.

108. Halldorsson, S.; Lucumi, E.; Gómez-Sjöberg, R.; Fleming, R.M.T. Advantages and challenges of microfluidic cell culture in polydimethylsiloxane devices. Biosens. Bioelectron. 2015, 63, 218-231, doi:10.1016/j.bios.2014.07.029.

109. Mehling, M.; Tay, S. Microfluidic cell culture. Curr. Opin. Biotechnol. 2014, 25, 95-102, doi:10.1016/j.copbio.2013.10.005.

(C) 2015 by the authors; licensee MDPI, Basel, Switzerland. This article is an open access article distributed under the terms and conditions of the Creative Commons Attribution license (http://creativecommons.org/licenses/by/4.0/). 